Eastern Illinois University

The Keep

Faculty Research \& Creative Activity

Biological Sciences

January 1995

\title{
Genetic Structure of Mosquitofish Populations in the Altamaha and Ogeechee Drainages of Georgia: Reporting an Undescribed Form in the Ocmulgee River
}

Jose D. Hernandez-Martich

University of Georgia

James M. Novak

Eastern Illinois University, jmnovak@eiu.edu

Michael H. Smith

University of Georgia

Paul E. Johns

University of Georgia

Follow this and additional works at: http://thekeep.eiu.edu/bio_fac

Part of the Biology Commons

\section{Recommended Citation}

Hernandez-Martich, Jose D.; Novak, James M.; Smith, Michael H.; and Johns, Paul E., "Genetic Structure of Mosquitofish Populations in the Altamaha and Ogeechee Drainages of Georgia: Reporting an Undescribed Form in the Ocmulgee River" (1995). Faculty Research \& Creative Activity. 213.

http://thekeep.eiu.edu/bio_fac/213

This Article is brought to you for free and open access by the Biological Sciences at The Keep. It has been accepted for inclusion in Faculty Research \& Creative Activity by an authorized administrator of The Keep. For more information, please contact tabruns@eiu.edu. 


\title{
Genetic Structure of Mosquitofish Populations in the Altamaha and Ogeechee Drainages of Georgia: Reporting an Undescribed Form in the Ocmulgee River
}

\author{
JOSE D. HERNANDEZ-MARTICH, ${ }^{*} \ddagger$ JAMES M. NOVAK, ${ }^{*}+$ MICHAEL H. SMITH ${ }^{*} \dagger$ \\ and PAUL. E. JOHNS* \\ "Savannah River Ecology Laboratory, Drawer E, Aiken, SC 28902, U.S.A.; \\ tInstitute of Ecology, University of Georgia, Athens, GA 30602. U.S.A.
}

Key Word Index: Gambusia holbrooki; mosquitofish; allozymes; genetic differentiation; heterozygosity; biogeography.

Abstract-An electrophoretic survey of genetic variation in mosquitofish populations of the Altamaha and Ogeechee drainages in Georgia revealed significant divergence $\left(F_{S T}=0.270\right)$ among populations within the Altamaha. Cluster analysis showed two lineages: one formed by populations from the Ogeechee drainage and the eastern and central Altamaha branches and another consisting of populations from the Ocmulgee River, the westernmost branch of the Altamaha drainage. These lineages may represent two independent forms. Average modified Rogers' genetic distance was 0.256 between the two groups. The Ocmulgee lineage had significantly higher multilocus heterozygosity $(\bar{H}=0.206)$ than the other one $(\bar{H}=0.120)$. The high heterozygosity in the Ocmulgee lineage is consistent with the hypothesis that it originated by hybridization. Populations in the Altamaha and Ogeechee exhibit spatial patterns of genetic characteristics similar to those previously described for populations in other drainages.

\section{Introduction}

Biochemical assessment of genetic diversity has been extensively used both as a taxonomic tool and to infer evolutionary factors influencing population structure (Smith et al., 1982, 1994). An earlier allozyme study of Coastal Plain populations of mosquitofish (Wooten et al., 1988) intended to end a controversy about the taxonomic status of eastern and western mosquitofishes. This study concluded that populations east of Mobile Bay (Alabama) belong to Gambusia holbrooki, whereas those on the west of the bay belong to G. affinis. Wooten et al. (1988) suggested the existence of two forms of G. holbrooki: Type I, which occurs from the Savannah River drainage (between Georgia and South Carolina) north to New Jersey, and Type II, which occurs from the Altamaha drainage (Georgia) south to Florida and eastward to Mobile Bay.

Distributions of the three mosquitofish forms were defined by Scribner and Avise (1993) based on a mtDNA and allozyme study. Their data suggest that the proposed Type I extends to the Ogeechee drainage (between the Savannah and Altamaha drainages) and also that the range of $G$. holbrooki extends to the mouth of Pascagoula River in Mississipi, where Wooten et al. (1988) reported G. affinis occurring in the headwaters. Finally, Scribner and Avise (1993) found populations of $G$. affinis in the headwaters of Savannah and other drainages where Wooten et al. (1988) had reported only $G$. holbrooki. Coexistence of these species in some locations had been documented (Wooten and Lydeard, 1990; Lydeard and Wooten, 1991).

¥Author to whom correspondence should be addressed. 
Another allozyme study was conducted on 85 Piedmont and Coastal Plain populations of mosquitofish from the Broad-Santee and Pee Dee drainages of the Carolinas and three Piedmont locations from the Altamaha drainage in Georgia (Hernandez, 1988). No evidence was found for the two proposed types of $G$. holbrooki when comparing the Altamaha populations (Type II) to those from the Carolinas' (Type I) drainages. However, the Altamaha samples were limited to the Piedmont of one river and thus, did not represent the entire drainage. Hernandez (1988) reported locally high heterozygosity and high differentiation in the drainages that he studied. He also found considerable genetic divergence between the Piedmont and Coastal Plain populations. Mosquitofish from Coastal Plain sites showed less among-population divergence within and between drainages, higher heterozygosity and more alleles than those from the Piedmont populations.

Hernandez (1988) attributed the pattern to isolation of Piedmont populations due to rising sea level. After the sea level dropped, mosquitofish occupied the Coastal Plain, where they could disperse within and between drainages. He also postulated that the pattern presently is maintained by Coastal Plain-to-Piedmont barrier effects of the Fall Line (a steep boundary between the Piedmont and Coastal Plain), by facilitation of downstream dispersal due to the one-way direction of the water flow, and by inter-drainage dispersal in the narrow, swampy area between the BroadSantee and Pee Dee drainages. Isolation due to sea level changes has also been invoked to explain the differentiation between the two mosquitofish species, between the two types of G. holbrooki (Smith et al., 1989; Scribner and Avise, 1993), and among other southeastern taxa (Avise, 1992).

The above findings underscore the need to sample mosquitofish populations on varying spatial scales to define the boundary between mosquitofish forms. Such sampling would also determine if the patterns reported by Hernandez (1988) in the Broad-Santee and Pee Dee occur in other drainages. Similar patterns in several drainages would further support his Piedmont isolation/downstream dispersal hypothesis to explain the origin of the pattern. Accordingly, we sampled several populations in the Piedmont and Coastal Plain of the Altamaha and Ogeechee drainages in Georgia. We also compared the spatial genetic patterns within and between these drainages with those observed by Hernandez (1988) in drainages of the Carolinas. Finally, we report the occurrence of two genetic forms of mosquitofish in the Altamaha drainage.

\section{Materials and Methods}

Mosquitofish were collected from 10 locations in the Ogeechee drainage and 21 locations in the Altamaha drainage (Fig. 1a). Thirty-six whole fish from each location were ground and used for electrophoresis (Hernandez-Martich and Smith, 1990). The genotype of each fish was scored for the following 12 enzymes (Enzyme Commission number and locus designation in parentheses): glucose-6-phosphate isomerase (EC 5.3.1.9; $G P /-A^{*}$ and $G P /-B^{*}$ ), malate dehydrogenase (EC 1.1.1.37; $s M D H-A^{*}, s M D H-B^{*}$ ), mannose-6-phosphate isomerase (EC 5.3.1.8; MPI-A*), phosphogluconate dehydrogenase (EC 1.1.1.44; $P G D H-A^{*}$ ), glycerol-3-phosphate dehydrogenase (EC 1.1.1.8; $G 3 P D H-A^{*}$ ), isocitrate dehydrogenase (EC 1.1.1.42; $m / D H P-A^{*}$ and $s / D H P-A^{*}$ ), and L-lactate dehydrogenase (EC 1.1.1.27; $L D H-A^{*}, L D H-B^{*}$ and $L D H-C^{*}$ ). The computer programs BIOSYS-1.7 (Swofford and Selander, 1989) and STATPAK (Northwest Analytical, 1982) were used to estimate genetic parameters and to analyze the data. Heterozygosity values were arcsin transformed before using them for any statistical test. Null hypotheses were rejected when $p \leq 0.05$.

\section{Results}

Two ( $L D H-C^{*}$ and $\left.s M D H-A^{*}\right)$ of the 12 loci examined were monomorphic. Genotypic frequencies were not significantly different from Hardy-Weinberg expected proportions for each locus in any of the populations. A hierarchical analysis of the genetic variance $\left(G_{S T}\right.$; Nei, 1977$)$ revealed $77 \%$ within populations and $23 \%$ among 


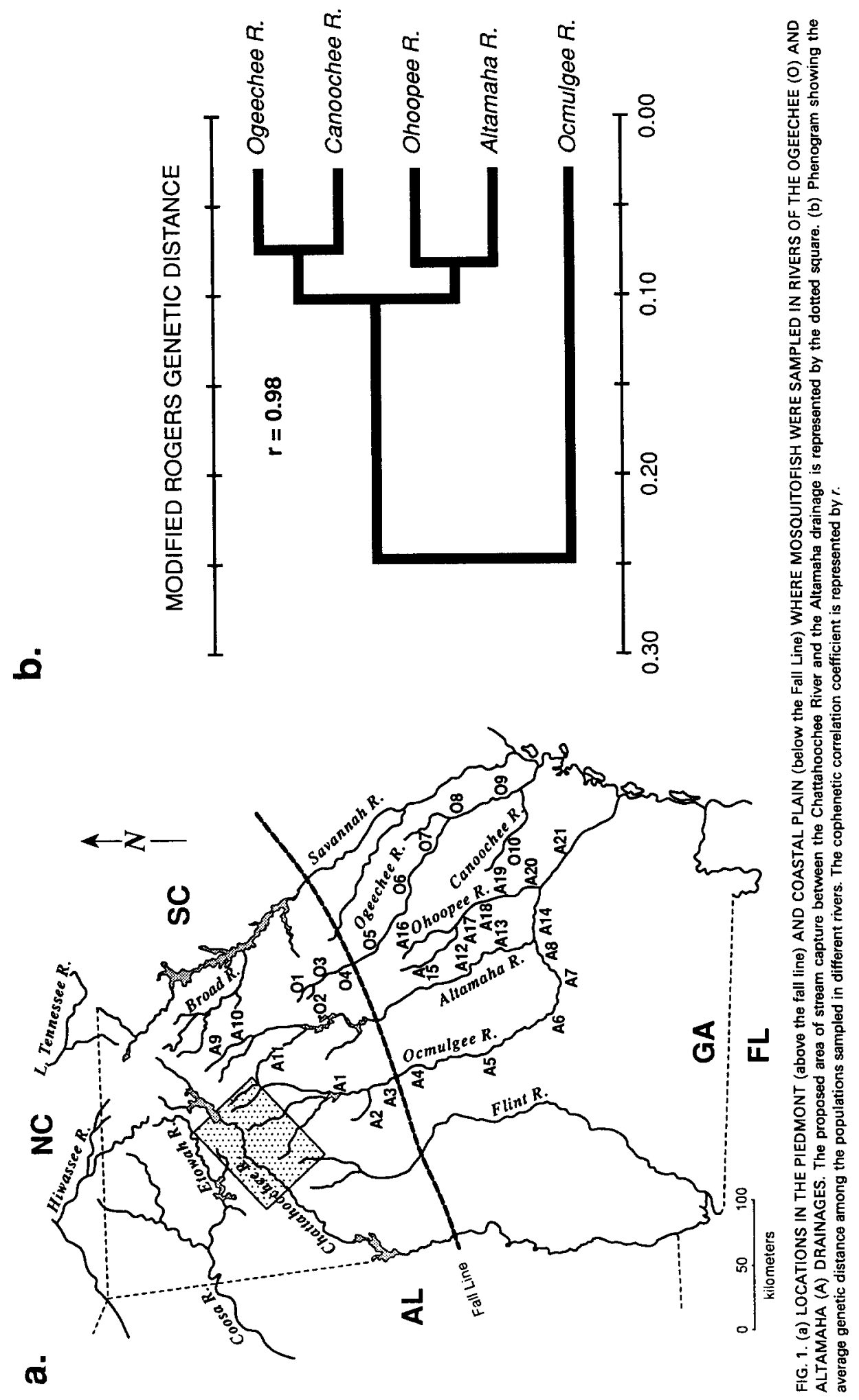


populations. The latter percentage was distributed as follows: $18 \%$ among local populations, $4 \%$ between Piedmont and Coastal Plain populations and $1 \%$ between the two drainages. Modified Rogers' genetic distance ( $D$; Wright, 1978) averaged across populations was 0.213 within the Piedmont, 0.201 between drainages within the Piedmont, 0.172 within the Coastal Plain, 0.181 between drainages within the Coastal Plain, 0.215 between the Piedmont and Coastal Plain, 0.215 within the Altamaha drainage, 0.112 within the Ogeechee drainage and 0.193 between drainages.

F-statistics (Wright, 1978), multilocus heterozygosity ( $H$; mean of the direct count of heterozygotes for each of the twelve loci examined) and the number of alleles (Na) per locus averaged across populations of the two drainages (separate and together) and their Piedmont and Coastal Plain sections are given in Table 1. Average $H$ did not differ significantly between populations of these sections $(t=0.107, \mathrm{df}=19$ for Altamaha; $t=0.634, \mathrm{df}=8$ for Ogeechee; $t=0.324, \mathrm{df}=29$ for both drainages). Populations of the Coastal Plain had higher $\bar{N}_{a}$ and more alleles (18 vs 12 in Altamaha and 12 vs 10 in Ogeechee) than those in the Piedmont. The difference in $\bar{N}_{a}$ was not significant $(t=1.314, \mathrm{df}=19$ for Altamaha; $t=0.338, \mathrm{df}=8$ for Ogeechee; $t=1.37, \mathrm{df}=29$ for both drainages).

A cluster analysis of the Coastal Plain populations using $D$ and the unweighted pair-group method with arithmetic averages (UPGMA; Sneath and Sokal, 1973) yielded a phenogram with two lineages. One lineage included the populations from the Ogeechee and two branches of the Altamaha drainage. The other lineage was formed by populations from the Ocmulgee River, the westernmost branch of the Altamaha drainage. Cophenetic correlation coefficient for the phenogram was 0.98 (Fig. $1 \mathrm{~b}$ ). Average $D$ between the two lineages was 0.256 , and their allele frequencies were significantly different at eight of 10 polymorphic loci and overall. Frequencies of $G 3 P D H-1^{*} 100, G P I-A^{*} 100$ and $P G D H-A^{*} 100$ were significantly lower in the Ocmulgee than in the other lineage $(t>3.0, \mathrm{df}=19$; Table 2 ). For these three loci and $m I D H P$ - $A^{*}$, single-locus heterozygosity $(h)$ averaged across populations was significantly higher in the Ocmulgee than in the other lineage $(t>2.3 ; \mathrm{df}=19)$. Multilocus heterozygosity for the Ocmulgee populations was always higher than for those in the other rivers $(H=0.170-0.250$ vs $0.080-$ $0.160)$. The Ocmulgee had significantly higher $\bar{H}, \bar{P}$ and $\bar{N}_{a}$ than the other lineage $(t>4.0, \mathrm{df}=19$; Table 3).

TABLE 1. NUMBER ( $N$ ) OF SAMPLING LOCATIONS BY DRAINAGE AND REGION, STANDARDIZED VARIANCE OF ALLELE FREQUENCIES $\left(F_{S}\right)$, INBREEDING OF AN INDIVIDUAL RELATIVE TO ITS POPULATION $\left(F_{I S}\right)$, INBREEDING OF AN INDIVIDUAL RELATIVE TO THE ENTIRE POPULATION SET ( $f_{I} ;$;right, 1978 ), AND MULTILOCUS HETEROZYGOSITY $(H)$ AND MEAN NUMBER OF ALLELES PER LOCUS $\left(N_{\imath}\right)$ AVERAGED ACROSS LOCATIONS FOR THE MOSOUITOFISH SAMPLED IN THE OGEECHEE AND ALTAMAHA DRAINAGES

\begin{tabular}{|c|c|c|c|c|c|c|}
\hline $\begin{array}{c}\text { Drainage(s) } \\
\text { Region }\end{array}$ & $N$ & $F_{S I}$ & $F_{/ s^{\dagger}}$ & $F_{r r}$ & $\bar{H} \pm \mathrm{SE}$ & $\bar{N}_{a} \pm \mathrm{SE}$ \\
\hline Ogeechee & 10 & 0.082 & 0.019 & 0.100 & $0.141 \pm 0.006$ & $1.64 \pm 0.04$ \\
\hline Piedmont & 4 & 0.101 & 0.003 & 0.104 & $0.146 \pm 0.011$ & $1.58 \pm 0.08$ \\
\hline Coastal Plain & 6 & 0.047 & 0.031 & 0.076 & $0.138 \pm 0.006$ & $1.71 \pm 0.05$ \\
\hline Coastal Plain & 15 & 0.197 & -0.016 & 0.185 & $0.141 \pm 0.014$ & $1.65 \pm 0.06$ \\
\hline Both Drainages & 31 & 0.236 & -0.003 & 0.233 & $0.142 \pm 0.009$ & $1.66 \pm 0.03$ \\
\hline Piedmont & 10 & 0.239 & -0.006 & 0.235 & $0.146 \pm 0.016$ & $1.60 \pm 0.05$ \\
\hline Coastal Plain & 21 & 0.193 & -0.002 & 0.191 & $0.140 \pm 0.010$ & $1.69 \pm 0.04$ \\
\hline
\end{tabular}

- Deviation of each $F_{5 r}$ from 0 was significant $(\rho \leq 0.05$; Workman and Niswander, 1970).

tDeviation of each $F_{/ s}$ from $O$ was not significant $(\rho>0.05$; $\mathrm{Li}$ and Horvitz, 1953). 
TABLE 2. ALLELE FREQUENCIES (a) OF MOSQUITOFISH POPULATIONS FROM THE OCMULGEE AND OTHER RIVERS OF THE ALTAMAHA AND OGEECHEE DRAINAGES AND RESULTS OF CHI-SQUARE TESTS FOR THE DIFFERENCES IN \& BETWEEN THE TWO SETS OF POPULATIONS ( $p \leq 0.05$ is significant)

\begin{tabular}{|c|c|c|c|c|c|}
\hline \multirow[b]{2}{*}{ Locus"allelet } & \multicolumn{2}{|c|}{$a$} & \multirow[b]{2}{*}{ Chi-square } & \multirow[b]{2}{*}{ df } & \multirow[b]{2}{*}{$p$} \\
\hline & Ocmulge日 & Other rivers & & & \\
\hline G3PDH-1"76 & 0.182 & 0.093 & & & \\
\hline 700 & 0.670 & 0.893 & & & \\
\hline$* 117$ & 0.148 & 0.014 & 143.82 & 2 & 0.000 \\
\hline GPI-A*60 & 0.539 & 0.018 & & & \\
\hline$\cdot 100$ & 0.453 & 0.982 & & & \\
\hline .125 & 0.008 & 0.000 & 662.66 & 2 & 0.000 \\
\hline$G P /-B^{*} 66$ & 0.100 & 0.289 & & & \\
\hline$" 100$ & 0.894 & 0.711 & & & \\
\hline .140 & 0.006 & 0.000 & 47.85 & 2 & 0.000 \\
\hline$m I D H P-A^{*} 100$ & 0.969 & 0.981 & & & \\
\hline$\cdot 118$ & 0.014 & 0.003 & & & \\
\hline$\cdot 132$ & 0.017 & 0.016 & 9.70 & 2 & 0.008 \\
\hline$S / D H P-A^{*} 100$ & 0.867 & 0.754 & & & \\
\hline$\cdot 161$ & 0.126 & 0.000 & & & \\
\hline$\bullet 175$ & 0.007 & 0.246 & 16.52 & 2 & 0.001 \\
\hline$\angle D H-A^{*} 95$ & 0.000 & 0.094 & & & \\
\hline$" 100$ & 1.000 & 0.006 & 2.64 & 1 & 0.104 \\
\hline$L D H-B^{*} 79$ & 0.003 & 0.000 & & & \\
\hline$\cdot 100$ & 0.997 & 1.000 & 2.67 & 1 & 0.102 \\
\hline$S M D H-B^{*} 65$ & 0.000 & 0.003 & & & \\
\hline$\cdot 100$ & 0.773 & 0.842 & & & \\
\hline$\cdot 150$ & 0.227 & 0.155 & 8.02 & 2 & 0.018 \\
\hline$M P I-A^{*} 93$ & 0.014 & 0.017 & & & \\
\hline .100 & 0.806 & 0.859 & & & \\
\hline$* 107$ & 0.181 & 0.124 & 9.10 & 2 & 0.011 \\
\hline$P G D H-A^{*} 89$ & 0.011 & 0.003 & & & \\
\hline .100 & 0.491 & 0.985 & & & \\
\hline$\cdot 116$ & 0.497 & 0.011 & 476.44 & 2 & 0.000 \\
\hline Overall & & & 1379.40 & 18 & 0.000 \\
\hline
\end{tabular}

$+\angle D H-C^{*}$ and $S M D H-A^{*}$ were monomorphic.

\section{Discussion}

High genetic diversity within populations and high divergence among local populations like those observed in the Altamaha and Ogeechee mosquitofish occur in the Broad-Santee and Pee Dee drainages (Hernandez, 1988). In all these drainages, mating within populations occurs randomly as indicated by the low inbreeding coefficient of an individual relative to its population $\left(F_{I S} ;\right.$ Table 1 ; Hernandez, 1988). Differentiation of populations between the Altamaha and Ogeechee and between Broad-Santee and Pee Dee is greater in the Piedmont than in the Coastal Plain. These four drainages also exhibit lower amongpopulation differentiation within drainages for the Coastal Plain than for the Piedmont populations. In the Ogeechee and Altamaha, as in the Broad-Santee and Pee Dee (Hernandez, 1988) and the Savannah River (Smith et al., 1983), there are more alleles in the Coastal Plain than in the Piedmont populations, and there is high genetic differentiation between populations of these regions. These findings are consistent with the hypothesis that mosquitofish populations were isolated in the Piedmont when the sea level was high, that within-drainage dispersal has occurred mainly in a downstream direction after the sea level dropped, and that interdrainage dispersal has occurred mostly within the Coastal Plain (Hernandez, 1988). 


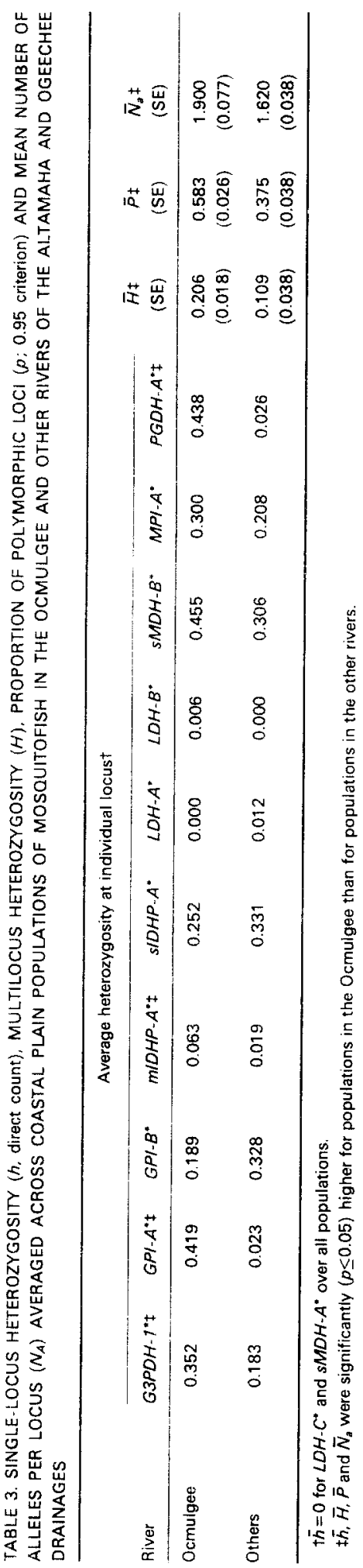


No significant difference in heterozygosity was found between Piedmont and Coastal Plain mosquitofish for the Altamaha and Ogeechee as reported for the Broad-Santee and Pee Dee drainages (Hernandez, 1988). Piedmont populations in Altamaha and Ogeechee exhibit higher heterozygosity than Piedmont populations in other drainages perhaps because they may contain hybrids of G. holbrooki with $G$. affinis. The latter species could be present in the Piedmont of Altamaha due to stream capture from the Chattahoochee River to the Ocmulgee and/or Altamaha Rivers (Fig. 1a). Gambusia affinis has been found in the Piedmont Savannah and Chattahoochee Rivers, which are occupied mostly by $G$. holbrooki. The presence of $G$. affinis in these rivers has been attributed to stream capture with branches of Alabama and Tennessee drainages (Lydeard and Wooten, 1991). Although such a stream capture has not been reported for either the Ogeechee or Altamaha, its occurrence is likely (Jenkins et al., 1971).

Standardized variance of allele frequencies $\left(F_{S T}\right.$; Table 1$)$ and $D$ values suggest a high degree of genetic differentiation among populations within the Altamaha drainage. The cluster analysis shows that part of this differentiation occurs between populations from the Ocmulgee River and those from other rivers of this drainage (Fig. 1b). The Ocmulgee River may harbor a mosquitofish form different from that in the other rivers of the Altamaha and Ogeechee drainages. This conclusion is strongly supported by the high $D$, and differences in allele frequencies, and in $\bar{h}, \bar{H}, \bar{P}$ and $\bar{N}_{a}$ among their populations (Tables 2 and 3). Average genetic distance between these two forms is almost as high as that reported between the G. holbrooki Types I and II by Wooten et al. (1988), which suggests that the two forms in the Altamaha may correspond to these types. However, $\bar{H}$ for the Ocmulgee populations $(\bar{H}=0.206)$ is considerably higher than that reported for each type of $G$. holbrooki (Type I: $\bar{H}=0.108$; Type II: $\bar{H}=0.118)$ and $G$. affinis $(\bar{H}=0.055)$. The differences in $\bar{H}$, between this study and that of Wooten et al. (1988) cannot be attributed to sampling error because we scored almost the same loci. Thus, the Ocmulgee populations do not seem typical of any of the three forms described by Wooten et al. (1988). Their study and Scribner and Avise's (1993) study failed to detect the occurrence of the two forms that may occur in the Altamaha drainage. This was because the former study did not include samples from the Ocmulgee and the latter had only a single sample from this river. Furthermore, Scribner and Avise's (1993) data show that their Ocmulgee sample exhibits a mtDNA haplotype not found elsewhere in the Altamaha drainage.

The occurrence of an Ocmulgee form different from the one in the other branches of the Altamaha drainage can be explained by invoking ecological and/or historical events. Environmental factors that differ between the Ocmulgee and the other branches may have selected for different forms in those rivers. Unfortunately, we do not have pertinent data to document any environmental difference between these rivers that may account for such selection. A historical event that might have contributed to the differentiation of the Ocmulgee mosquitofish was their isolation due to changes in sea level. Since the southeastern fish fauna originated (probably 24-37 mya; Robison, 1986), the shore line has fluctuated above and below the present sea level. It has been postulated that the coast was more than $80 \mathrm{~m}$ above the present sea level between 10 and 16 mya (Miocene), between 4 and 5 mya (Pliocene) and between 0.5 and 1 mya (Aftonian interglacial stage of the Pleistocene), and that it was more than $65 \mathrm{~m}$ above the present sea level from 0.2 to 0.4 mya (Yarmouth interglacial stage of the Pleistocene; MacNeil, 1950; Vail and Hardenbol, 1979). The present elevation of the Ocmulgee River is only $76 \mathrm{~m}$ at the Fall Line and $30 \mathrm{~m}$ where it joins the Altamaha River. Thus, the Ocmulgee River has been separated from the rest of the Altamaha drainage for several long periods. That isolation could have allowed mosquitofish of this river to evolve independently of 
those in the rest of the drainage, but it cannot explain the high heterozygosity found in all its populations.

Given the high heterozygosity of the Ocmulgee mosquitofish, they could have originated from the hybridization between either $G$. affinis and $G$. holbrooki, or $G$. holbrooki Types I and II. We do not know any locus with allele frequencies that could be used to distinguish the two types of G. holbrooki. Among the loci used to distinguish the two species (Wooten et al., 1988; Lydeard and Wooten, 1991), G3PDH-A* and PGDH-A* were included in our survey. In all of our samples, except those from the Ocmulgee, the 100 alleles of these loci exhibit frequencies typical of $G$. holbrooki. For the Ocmulgee populations, these frequencies are lower than those reported for $G$. holbrooki, but higher than that for $G$. affinis (Wooten et al., 1988). In addition, the frequency of GPI-A*100 is less than 0.5 in populations of the Ocmulgee and, in those of the Ogeechee and the rest of the Altamaha, it is close to 1.0 as in other populations of G. holbrooki (Smith et al., 1983; Hernandez, 1988).

In conclusion, genetic patterns observed among mosquitofish in the Carolinas and Georgia drainages are consistent with the hypothesis that Piedmont populations of mosquitofish were isolated by the rising sea level in the past. After sea level dropped, mosquitofish have dispersed mainly downstream. Dispersal between drainages may have occurred within the Coastal Plain. Coastal Plain populations from the Ogeechee and Altamaha drainages excluding the Ocmulgee River belong to $G$. holbrooki, whereas those from the Ocmulgee may belong to a form that originated by hybridization between $G$. affinis and $G$. holbrooki. The Piedmont parts of these drainages may harbor pure and mixed populations of these species.

Acknowledgements-We thank Rosibel Hernandez for her help during the sampling and Aline De La Perriere for her assistance with the illustrations. We also thank Dr Margaret Mulvey, Karen Kandl, Lee Ann Woodward and Craig Stockwell for their insightful comments. This research was supported under contract DE-AC09-76SR00819 between the U. S. Department of Energy and the University of Georgia.

\section{References}

Avise, J. C. (1992) Molecular population structure and the biogeographic history of a regional fauna: A case history with lessons for conservation biology. Oikos 63, 62-76.

Hernandez, J. D. (1988) Genetic variation in eastern mosquitofish (Gambusia holbrooki Girard) from the Piedmont and Coastal Plain of the Altamaha, Broad-Santee and Pee Dee Drainages. Master's Thesis, University of Georgia.

Hernandez-Martich, J. D. and Smith, M. H. (1990) Pattern of genetic variation in eastern mosquitofish (Gambusia holbrooki Girard) from the Piedmont and the Coastal Plain of three drainages. Copeja 1990. $619-630$.

Jenkins, R. E., Lachner, E. A. and Schwartz, F. J. (1971) Fishes of the Central Appalachian drainages: Their distribution and dispersal. In The Distributional History of the Biota of the Southern Appalachians. Part III: Vertebrates (Holtz, P. C., ed.), pp. 43-117. Virginia Poly. St. Univ., Res. Div. Monogr. 4, Blacksburg, VA, U.S.A.

Li, C. C. and Horvitz, D. G. (1953). Some methods of estimating the inbreeding coefficient. Am. J. Hum. Genet. 5, 107-117.

Lydeard C. and Wooten, M. C. (1991) Occurrence of Gambusia affinis in the Savannah and Chattahoochee drainages: Previously undescribed geographic contacts between $G$. affinis and $G$. holbrooki. Copeia 1991, 1111-1116.

MacNeil, F. S. (1950) Pleistocene Shore Lines in Florida and Georgia. U.S. Geol. Surv. Prof. Pap. 221 -F, pp. 95-106.

Nei, M. (1977) F-statistics and analysis of gene diversity in subdivided populations. Ann. Hum. Genet. 41 , 225-233.

Northwest Analytical (1982) The NWA STATPAK, Version 2.1. Northwest Analytical Inc., Portland, OR, U.S.A.

Robison, H. W. (1986) Zoogeographic implications of Mississipi River Basin. In The Zoogeography of North American Freshwater Fishes (Hocutt, C. H. and Wiley, E. O., eds), pp. 267-285. John Wiley and Sons, New York, NY, U.S.A. 
Scribner, K. T. and Avise, J. C. (1993) Cytonuclear genetic architecture in mosquitofish populations and the possible roles of introgressive hybridization. Molec. Ecol. 2, 139-149.

Smith, M. H., Hernandez-Martich, J. D., Novak, J. M., Stangel, P. W. and Lowery, J. G. (1994) Bibliography of Electrophoretic Studies of Biochemical Variation in Natural Vertebrate Populations. Vol. 2: 1981-1989. Savannah River Site National Environmental Research Park SRO-NERP-23.

Smith, M. H., Scribner, K. T., Hernandez, J. D. and Wooten, M. C. (1989) Demographic, spatial, and temporal genetic variation in Gambusia. In Ecology and Evolution of Livebearing Fishes (Poeciliidae) (Meffe, G. K. and Snelson, F. F., eds), pp. 235-257. Prentice-Hall Inc., Englewood Cliffs, NJ, U.S.A.

Smith, M. W., Aquadro, C. F., Smith, M. H., Chesser, R. K. and Etges, W. J. (1982) Bibliography of Electrophoretic Studies of Biochemical Variation in Natural Vertebrate Populations. Texas Tech Press, Lubbock, TX, U.S.A.

Smith, M. W., Smith, M. H. and Chesser, R. K. (1983) Biochemical genetics of mosquitofish. I. Environmental correlates, and temporal and spatial heterogeneity of allele frequencies within a river drainage. Copeia 1983, 182-193.

Sneath, P. H. A. and Sokal, R. R. (1973) Numerical Taxonomy. W. H. Freeman \& Co., San Francisco, CA, U.S.A.

Swofford, D. R. and Selander, R. (1989) Biosys-1. A Computer Program for the Analysis of Allelic Variation in Population Genetics and Biochemical Systematics. Release 1.7. Natural History Survey, Urbana, IL, U.S.A.

Vail, P. R. and Hardenbol, J. (1979) Sea-level changes during the Tertiary. Oceanus 22(3), 71-79.

Wooten, M. C. and Lydeard, C. (1990) Allozyme variation in a natural contact zone between Gambusia affinis and Gambusia holbrooki. Biochem. Syst. Ecol. 18, 169-173.

Wooten, M. C., Scribner, K. T. and Smith, M. H. (1988) Genetic variability and systematics of Gambusia in the Southeastern United States. Copeia 188, 283-289.

Workman, P. L. and Niswander, J. D. (1970) Population studies on southwestern Indian tribes. II. Local genetic differentiation in the Papago. Am. J. Hum. Genet. 22, $24-49$.

Wright, S. (1978) Evolution and the Genetics of Populations. IV. Variability Within and Among Natural Populations. University of Chicago Press, Chicago, IL, U.S.A. 